This item was submitted to Loughborough's Research Repository by the author.

Items in Figshare are protected by copyright, with all rights reserved, unless otherwise indicated.

\title{
A review of corporate social responsibility practices in developing countries
}

\section{PLEASE CITE THE PUBLISHED VERSION}

http://doi.org/10.14455/ISEC.res.2017.130

\section{PUBLISHER}

(C) ISEC Press

\section{VERSION}

VoR (Version of Record)

\section{PUBLISHER STATEMENT}

This work is made available according to the conditions of the Creative Commons Attribution-NonCommercialNoDerivatives 4.0 International (CC BY-NC-ND 4.0) licence. Full details of this licence are available at: https://creativecommons.org/licenses/by-nc-nd/4.0/

\section{LICENCE}

CC BY-NC-ND 4.0

\section{REPOSITORY RECORD}

Alotaibi, Ali, Francis Tekyi Edum-Fotwe, and Andrew D.F. Price. 2019. "A Review of Corporate Social Responsibility Practices in Developing Countries". figshare. https://hdl.handle.net/2134/32491. 


\title{
A REVIEW OF CORPORATE SOCIAL RESPONSIBILITY PRACTICES IN DEVELOPING COUNTRIES
}

\author{
ALI ALOTAIBI, FRANCIS EDUM-FOTWE, and ANDREW PRICE \\ Dept of Civil and Building Engineering, Loughborough University, \\ Loughborough, United Kingdom
}

\begin{abstract}
The construction industry plays a vital role in every economy by contributing substantially to the national gross domestic product (GDP). Despite the significance of the industry, construction is often criticized for adversely impacting society and the environment through the nature of its work. Managing societal and environmental impacts are at the heart of corporate social responsibility (CSR) which is a critical factor for achieving long-term competitiveness. CSR has been adopted by many industries to address the negative impacts that result from their operations. Research in CSR within the construction industry is limited and still in its infancy, especially in the Kingdom of Saudi Arabia (KSA) where there is a negligible uptake of CSR activities and a lack of strategies and guidelines. The key question here is why the construction industry in KSA has not fully embraced the concept of CSR. This article presents the results of a literature study undertaken to develop an understanding of the reasons that militate against the implementation of CSR in general, and specifically in construction within KSA. The paper adopts a structured approach to analyze materials published on CSR, in general, and how it has been applied in the construction sector, including KSA. The analysis indicates that there are critical factors that have hampered the fulfillment of CSR requirements in construction. A lack of awareness and knowledge is ranked as the greatest barrier, and the lack of a practical and theoretical framework to examine the level of CSR implementation closely follows in tow. The analysis suggests that CSR within KSA is currently at a basic level and focused on philanthropic activities. It also indicates that there is a need to go beyond this basic level by developing an appropriate framework to assist KSA construction companies in integrating CSR fully into their business practice.
\end{abstract}

Keywords: Construction, Company, Framework, Barriers, KSA.

\section{INTRODUCTION}

Corporate Social Responsibility (CSR) is an evolving concept that is gaining the attention of academics and practitioners, and continues to grow in importance especially for business organizations. According to Carroll et al. (2010), the concept carries different meanings for various stakeholders. Such differences make it essential to provide an accepted and complete working definition of the concept to support the study that is reported in this paper. The definition of CSR adopted for the study is one advanced by the Constructing Excellence (2011) as "the commitment to integrate socially responsible values and concerns of stakeholders into its operations in a manner that fulfills and exceeds current legal and commercial expectations". The underlying ethos of such a 
definition is one of having values that transcend the bottom-line which is the main driver for most businesses. Recognizing the need for such an ethos, Zhao et al. (2012) suggest that when implemented effectively, CSR can have a positive effect on businesses and other organizations by helping to address their economic and environmental impacts, as well as meeting the expectations of stakeholders. Engin and Akgoz (2016) suggest that a CSR orientation will call for organizations to adopt much longer-term perspective for their economic performance rather than the short-term actions, which often prove harmful socially and/or environmentally. Other writers on the subject suggest various advantages that accrue from the adoption of CSR practices, to include a more relevant strategy, responding to current global trends, useful ethical standing, attracting the right and loyal staff and achieving a competitive advantage (Wu et al. 2015). While it is easy to argue that such practices may exist in many developing countries, the evidence points to an inertia that militates against the adoption of CSR (Khan et al. 2013).

This paper critically appraises various reasons for the lack of effective uptake of CSR practices within KSA construction industry. The underpinning argument for the use of KSA is that it shares common practices and industry features with many developing countries. As such, any lessons would serve as a great benefit to countries in that category. The paper also addresses the context of construction, the challenges of adopting CSR, and alternative approaches to CSR implementation. It also provides systematic analyses of essential and relevant work on the subject to crystalize the key factors that should provide a foundation for harnessing CSR practice within KSA.

\section{SOCIO-ECONOMIC IMPACT OF CONSTRUCTION}

Hillebrandt (2000) described construction as a sector associated with processes of procuring, producing, altering, repairing, maintaining and demolishing building and civil engineering works. This industry contributes substantially to the growth of national GDP of every country. Flanagan (2014) indicated that the global output of construction was estimated at around US\$6.8 trillion in 2013, and this accounts for about $10 \%$ of the annual global GDP. Furthermore, it contributes to economic development nationally and globally, through a combination of architecture, engineering and provision of job opportunities as well as the interaction with other industries which help in accelerating economic growth (Hillebrandt 2000, Lichtenstein et al. 2013). Parallel to its significant contribution to the economy, construction significantly impacts on society and the environment (Barthorpe 2010). It has been suggested that the industry consumes $50 \%$ of raw materials and energy, which often leads to land degradation and resource depletion, as well as the misuse of water, gas emissions, dust noise and pollution (Lu 2013). With regards to health and safety, construction is arguably one of the most dangerous sectors has been accused of having a status of poor quality and services, alongside bad safety and poor stakeholder relationships (Pinto et al. 2011).

\section{CSR IN CONSTRUCTION}

Jiang and Wong (2015) propose that the significant impacts of construction activities on the physical environment and wider communities necessitate a focus on CSR as an essential input into sustainable construction. In many developed countries CSR in construction is largely directed at areas such as climate change, ethics, human rights, community interaction, and sustainable development techniques, as these are the aspects where potential breaches lie (Lichtenstein et al. 2013). All the same, many contractors are often criticized for poor performance in the fulfillment of their CSR obligations (Barthorpe 2010, Murray and Dainty 2013). This is largely due to the lack of knowledge on how to effectively implement CSR and also the lack of guidelines for industry. Responding to this lack of knowledge, Loosemore and Lim (2016) affirm that there is a lack of comprehensive CSR strategies within the industry, and a missing link between CSR and economic 
performance. The position of Loosemore and Lim (2016) would appear to suggest that the problem of a lack of adoption for CSR is not limited only to developing economies. This makes any solution from the developing countries potentially viable for establishing alternative practices for developing economies. So, establishing such a link and providing guidance for CSR strategy would be invaluable to the adoption of practices in construction. To achieve such a link, it would be useful to depict the nature of factors that influence the implementation of CSR in developing countries.

\section{CONTEXT OF CSR IN KSA CONSTRUCTION}

The Kingdom of Saudi Arabia (KSA) is a developing country with a high GDP. The KSA is the biggest oil exporting country in the world, with the revenues from oil accounting for $80 \%$ of the national budget (Ashraf 2015). However, the Government has a vision of a more diverse economy that involves the private sector participation in the development of the country as part of public sector CSR in job creation (Maqbool 2015). Construction is the second largest sector and the fastest growing amongst Gulf Countries, representing 6-10\% of GDP (Al-emad and Nagapan 2015). According to Opoku and Abdul-Muhmin (2010) it provides a vital role in resolving some of the issues that arise from social problems, such as explosive population growth. The solutions provided by construction can therefore be seen as CSR contribution by the industry. Almahmoud and Doloi (2013) cited research by others, who concluded that there is little evidence of exemplary practices of CSR in construction within KSA. The lack of CSR is typified by breaches in health and safety, as well as low levels of productivity form such issues as high project costs, delays, and waste across the project life cycle (Assaf and Al-Hejji 2006). A major health and safety breach in construction in KSA is outlined in the following example. Batrawy (2015) reported that one of the worst disasters in construction in KSA was the collapse in Makkah, killing about 100 people, and injuring around 250 in September 2015. This disaster raised concerns as to how much construction organizations care about relevant stakeholder benefits from their operations and led to questions of their CSR practice. Such incidents and the high number of people killed or seriously injured on construction sites, and waste production, appear to suggest a lack or neglect of CSR in KSA construction.

The concept of CSR in KSA is still in its infancy, and there are many aspects that are still evolving. Razak (2015) has suggested that the KSA Government is yet to actively promote CSR at a strategic or policy level. However, there is a growing recognition of the importance of CSR within KSA Government, society, public and private organizations (Ali and Al-aali 2012). Maqbool (2015) draws attention to the view that, while global efforts in CSR are focused on issues such as human rights, environment, labour rights and anti-corruption, in KSA the emphasis appears to be on developing the human and social capital of the country and philanthropic activity requirements (Khan et al. 2013). This is a reflection of the political challenges and cultural context of KSA society. There is little evidence within literature on empirical work based on CSR constructs within the KSA context (Mandurah et al. 2012, Maqbool 2015). Little research has been undertaken on how CSR can be used to address societal issues caused by increasing development, whilst improving an organization's productivity.

\section{METHODOLOGY}

Due to the nature of this research, a qualitative approach was adopted. To develop a consistent foundation for addressing CSR, the study adopted a review of literature to develop an understanding of the current CSR practices in KSA. The review followed a systematic process by employing relevant keywords and concepts that relate to the research topic in hand. Then, different sources were used to collect available information including textbooks, peer review journals and conference papers, professional magazines, government publications, dissertations and theses, workshops and 
technical reports, as well as online database systems and Indexes and to identify suitable articles. In addition, the key CSR activities were extracted from ISO 26000 to establish the principles and the core issues for the review. A total of 200 articles were returned form the initial interrogation, out of which 50 papers were found to be related to construction. Also, 15 papers were identified as relating to CSR in KSA which had no connection to construction. The assembled set of 50 articles were scanned at three levels of abstracts, keywords, and contents based on the identified activities from ISO 26000 and the 15 articles on KSA CSR that had no bearing on construction. The relevant materials were analyzed, and the output recorded and classified. Collecting recent publications and latest editions of the relevant materials was a continuous process throughout the research period, which ensured that up to date knowledge, latest developments and relevant contributions to the study subject were captured.

\section{RESULTS OF ANALYSIS}

Collectively, the review of the 50 papers identified the environment as the primary external issue, and health and safety, as the primary internal CSR issue that should receive attention in CSR practice. The results also showed that organizations focused on community development and philanthropic activities more than sustainable development. Moreover, the study suggests that there is much more to do in embedding good CSR in construction. Figure 1 presents the CSR areas of emphasis in construction within different countries compared with the ISO 26000 standard. Figure 2 elaborates the most notable barriers and drivers of CSR that emerged out of the analysis. Together, they form a strong foundation for addressing industry-wide implementation of CSR.

\section{DISCUSSION}

The results of the analysis show a considerable discrepancy between the standard and the practices adopted in many developing countries, including that of the KSA. Just as in other industries, construction in KSA places undue emphasis on lowest price, rather than best value. The ISO 26000 standard provides construction with a set of activities that can facilitate a link to society in terms of its performance measures to overcome its current narrow focus. The narrow view has an adverse and often inadequate impact on the performance of the industry in terms of time, cost and quality. As a result, it is vital for construction companies to develop and implement their CSR practices with the communities in which they operate. The rationale is that CSR practices have to relate to the context in which they are set.

This paper has also highlighted certain distinctive characteristics of CSR in developing countries, such as less formalized approaches to CSR implementation, and more superficial and philanthropic outlook in their nature. The benefits of adoption of CSR in the construction industry are yet to be fully realized, and keeping in view the local socio-political landscape, it would be useful to determine the most relevant CSR models for construction in different settings.

The literature analysis presented in this paper indicates that the main barrier for the implementation of CSR is the lack of awareness and knowledge as well as a lack of consensus on how CSR is defined and the principles that might be contained in any CSR model. This is further compounded by the absence of a CSR reporting framework for construction (Wilson et al. 2011).

\section{CONCLUSION}

The paper has presented CSR concepts and argued their relevance in construction. It offers recommendations for a better alignment between CSR implementation and performance measures in construction, to meet the expectations of stakeholders and the public in general. In particular, the need to ensure the implementation of CSR is focused on the well-being of communities with regards 
to environmental, social and economic conditions. The review showed a narrow interpretation of the CSR concept within KSA where it is taken mainly as philanthropic activities, which falls short of the full responsibilities of a responsible business. This is because CSR is a complex phenomenon, which means different things to different people. With regards to the areas involved in CSR, there are environmental, social, economic, legal and ethical areas which need to be satisfied and philanthropic activities are based on religious requirements. However, the aim of CSR is to achieve long-term objectives not simply spending money. Additionally, the lack of CSR awareness and the absence of a theoretical and practical framework within developing countries like KSA, has hindered its implementation. The militating factors that emerged from the analysis can be harnessed to play an important role in the daily practices of companies, and construction companies that have to develop an effective CSR to support their activites.

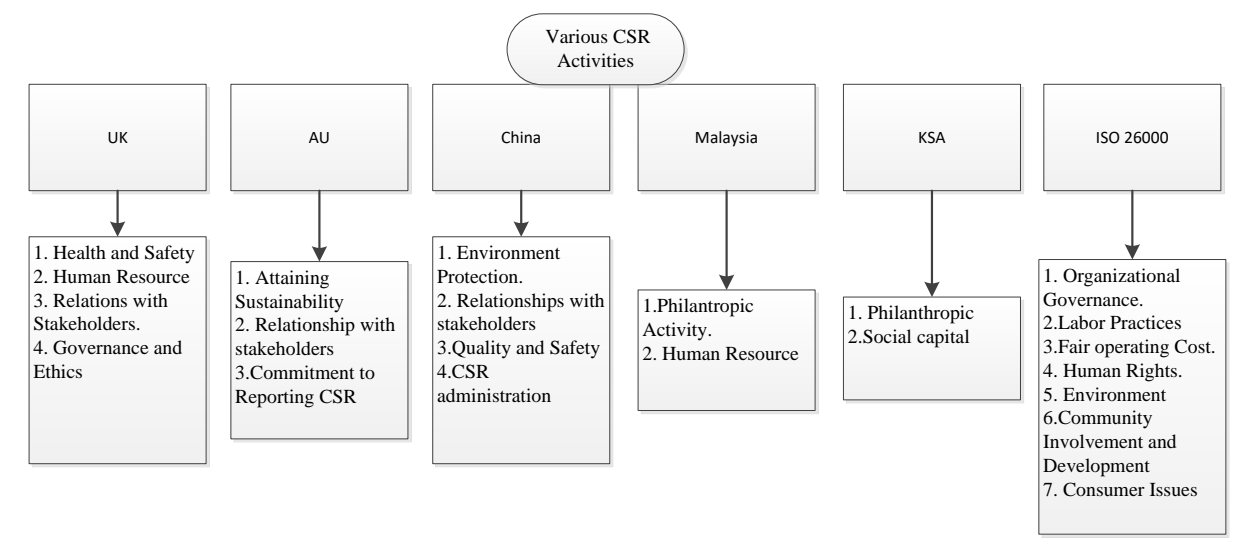

Figure 1. Various CSR activities in the construction sector for selected countries.

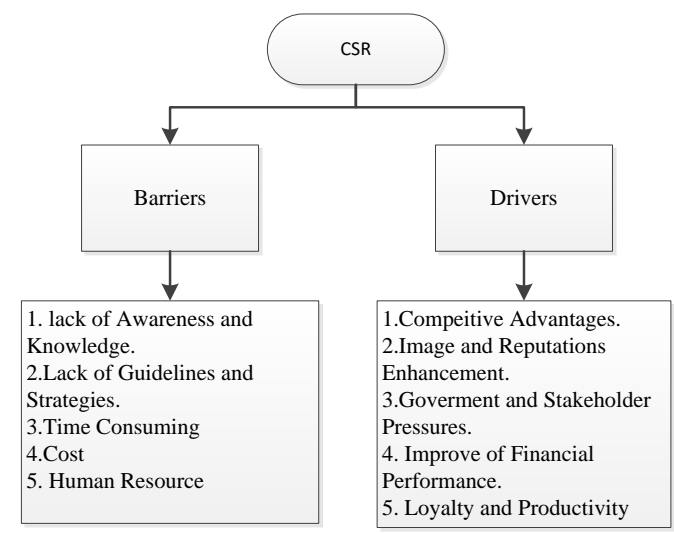

Figure 2. Barriers and drivers for implementing CSR.

\section{References}

Al-emad, N. and Nagapan, S., Identification of Delay Factors from Mecca's Construction Experts Perspective. (IJSET), 6(2), 16-25, 2015.

Ali, A. J. and Al-aali, A., Corporate Social Responsibility in Saudi Arabia. Middle East Policy, 19(4), 2012.

Almahmoud, E., and Doloi, H., Identifying the Underlying Social Factors Within Soudi Arabian Construction Industry. AUBEA Conference, Auckland, New Zealand, 2013. 
Ashraf, G., Budgetary Institutions, Fiscal Policy, and Economic Growth: the Case of Saudi Arabia. Economic Research Forum, Working Paper 967, 2015.

Assaf, S. A. and Al-Hejji, S.,Causes of Delay in Large Construction Projects. Int.J.Project Manage., Elsevier, 24(4), 349-357, 2006.

Barthorpe, S., Implementing Corporate Social Responsibility in the UK Construction Industry. Property Management, Emerald, 28(1), 4-17, 2010.

Batrawy, A., Saudi Arabia Partly Blames Construction Giant Binladin Group over Mecca Crane Disaster, 2015. Retrieved from http://globalnews.ca/news/2221825/saudi-arabia-partly-blames-binladin-group-incrane-deaths June, 2016.

Carroll, A. B., and Shabana, and K. M.,The Business Case for Corporate Social Responsibility: A Review of Concepts, Research and Practice. (IJMR), 12(1), 85-105, 2010.

Constructing Excellence., Corporate Social Responsibility,2011. Retrieved from http://constructingexcellence.org.uk/wp-content/uploads/2015/03/social_responsibility.pdf. July 2016.

Engin, E. and Akgoz, B., Corporate Social Responsibility In Turkey: An Analysis Through Web Sites. Journal of Business Research - Turk, 8(2), 18-18, 2016.

Flanagan, R. and Jewell, C., The Future is Now-Improving Construction Performance, Productivity, Process, and Profits- the China Perspective. Keynote Speech at the 19th Int. Symp. on the Advancement of Construction Management and Real Estate, Chongqing, China, 2014..

Hillebrandt, P. M., Economic Theory and the Construction Industry., Palgrave. Macmillan, 2000.

Jiang, W. and Wong, J. K. W., Key Activity Areas of Corporate Social Responsibility (CSR) in the Construction Industry: A Study of China. J.Cleaner Prod., Elsevier, 25, 1-11, 2015.

Khan, S. A., Al-Maimani, K. A., and Al-Yafi, W. A., Exploring Corporate Social Responsibility in Saudi Arabia: The Challenges Ahead. Journal of Leadership, Accountability and Ethics, 10(3), 65-79, 2013.

Lichtenstein, S., Badu, E., Owusu-Manu, D.-G., John Edwards, D., and D. Holt, G., Corporate Social Responsibility Architecture and Project Alignments. Journal of Engineering, Design and Technology, Emerald 11(3), 334-353, 2013.

Loosemore, M. and Lim, B. T. H., Linking Corporate Social Responsibility and Organizational Performance in the Construction Industry.Constr.Manage.Econ., Routledge, 6193(October), 1-16, 2016.

Lu, W. and Tam, V. W. Y., Construction Waste Management Policies and their Effectiveness in Hong Kong: A Longitudinal Review. Renewable Sustainable Energy Rev., Elsevier, 23, 214-223, 2013.

Mandurah,S. Khatib,J. and Al-Sabaan,S ., Corporate Social Responsibility Among Saudi Arabian Firms: An Empirical Investigation. The Journal of Applied Business Research, 28(5), 1049-1058, 2012.

Maqbool, S., An Overview of Programs in Saudi Arabia with Reference to Select Organizations. International Journal of Human Resources Studies, 5(2), 282-289, 2015.

Murray, M. and Dainty, A., Corporate Social Responsibility in the Construction Industry. London, Routledge, 2013.

Opoku, R. A. and Abdul-Muhmin, A. G., Housing Preferences and Attribute Importance among Low-Income Consumers in Saudi Arabia. Habitat International, Elsevier, 34(2), 219-227, 2010.

Pinto, A., Nunes, I. L., and Ribeiro, R. A., Occupational Risk Assessment in Construction Industry - Overview and Reflection. Saf.Sci., Elsevier, 49(5), 616-624, 2011.

Razak, R. A., Corporate Social Responsibility Disclosure and its Determinants in Saudi Arabia., Middle-East J. Sci.Res.,23(10): 2388-2398, 2015.

Wilson, L., Zuo, J., Zillante, G., Pullen, S., Burger, A., and Chiveralls, K., Corporate Social Responsibility in the Australian Construction Industry. The International Journal of Environmental, Cultural, Economic \& Social Sustainability.7(4), 110-120, 2011.

Wu, C.-L., Fang, D.-P., Liao, P.-C., Xue, J.-W., Li, Y., and Wang, T., Perception of Corporate Social Responsibility: The Case of Chinese International Contractors. J.Cleaner Prod., Elsevier, 107, 185-194, 2015.

Zhao, Z. Y., Zhao, X. J., Davidson, K., and Zuo, J., A Corporate Social Responsibility Indicator System for Construction Enterprises. J.Cleaner Prod., Elsevier, 29-30, 277-289, 2012. 